\title{
Biochemical analysis and the preliminary crystallographic characterization of D-tagatose 3-epimerase from Rhodobacter sphaeroides
}

\author{
Zhengliang Qi ${ }^{1,2,3}$, Zhangliang Zhu ${ }^{3}$, Jian-Wen Wang ${ }^{3}$, Songtao $\mathrm{Li}^{3}$, Qianqian Guo ${ }^{3}$, Panpan Xu ${ }^{3}$, Fuping Lu ${ }^{1,2,3,4^{*}}$ \\ and Hui-Min Qin ${ }^{1,2,3^{*}}$
}

\begin{abstract}
Background: D-Tagatose 3-epimerase epimerizes D-fructose to yield D-psicose, which is a rare sugar that exists in small quantities in nature and is difficult to synthesize chemically. We aim to explore potential industrial biocatalysts for commercial-scale manufacture of this rare sugar. A D-tagatose 3-epimerase from Rhodobacter sphaeroides (RsDTE) has recently been identified as a D-tagatose 3-epimerase that can epimerize $\mathrm{D}$-fructose to yield D-psicose with a high conversion rate.
\end{abstract}

Results: The purified RsDTE by Ni-affinity chromatography, ionic exchange chromatography and gel filtration forms a tetramer in solution. The maximal activity was in Tris- $\mathrm{HCl}$ buffer $\mathrm{pH} 8.5$, and the optimal temperature was at $35^{\circ} \mathrm{C}$. The product, D-psicose, was confirmed using HPLC and NMR. Crystals of RsDTE were obtained using crystal kits and further refined under crystallization conditions such as 10\% PEG 8000,0.1 M HEPES pH 7.5, and 8\% ethylene glycol at $20^{\circ} \mathrm{C}$ using the sitting-drop vapor diffusion method. The RsDTE homology model showed that it possessed the characteristic TIM-barrel fold. Four residues, Glu156, Asp189, Gln215 and Glu250, forms a hydrogen bond network with the active $\mathrm{Mn}$ (II) for the hydride transfer reaction. These residues may constitute the catalytic tetrad of RsDTE. The residues around $\mathrm{O} 1, \mathrm{O} 2$ and $\mathrm{O} 3$ of the substrates were conserved. However, the binding-site residues are different at $\mathrm{O} 4, \mathrm{O} 5$ and $\mathrm{O6}$. Arg1 18 formed the unique hydrogen bond with $\mathrm{O} 4$ of D-fructose which indicates RsDTE's preference of D-fructose more than any other family enzymes.

Conclusions: RsDTE possesses a different metal-binding site. Arg118, forming unique hydrogen bond with $\mathrm{O} 4$ of D-fructose, regulates the substrate recognition. The research on D-tagatose 3-epimerase or D-psicose 3-epimerase enzymes attracts enormous commercial interest and would be widely used for rare sugar production in the future.

Keywords: D-Tagatose 3-epimerase, D-Fructose, D-Psicose, Crystallization, Structural analysis, TIM-barrel fold

\section{Background}

D-Psicose, a rare sugar that exists in small quantities in nature, is a valuable low-calorie sweetener food additive $[1,2]$ due to its poor absorbance in the digestive tract and almost no energy. The supplemental D-psicose might be helpful for diabetic patients in preventing post prandial hyperglycemia $[3,4]$. D-Psicose is commercially

\footnotetext{
*Correspondence: Ifp@tust.edu.cn; huiminqin@tust.edu.cn

${ }^{3}$ College of Biotechnology, Tianjin University of Science and Technology, Tianjin, People's Republic of China

Full list of author information is available at the end of the article
}

produced by alkali isomerization. However, biosynthesis of rare sugars is environmentally friendly and sustainable with moderate reaction conditions and high efficiency compared with chemical synthesis $[5,6]$. Therefore, the most promising approach to produce $\mathrm{D}$-psicose is to use an enzymatic reaction catalyzed by D-psicose-tagatose 3-epimerase (DTE) or D-psicose 3-epimerase (DPE) [6-8]. DTE and DPE were named based on the substrate specificities toward D-tagatose or D-psicose, respectively. Both of these enzymes catalyze the epimerization of various ketohexoses, such as D-tagatose and D-fructose to 
D-sorbose and D-psicose, respectively, by catalyzing the epimerization at carbon-3 (C3) position [9-11].

The characterization study of DTE/DPE from Pseudomonas cichorii (PcDTE, 290 amino acid residues, 32,615 Da) and Agrobacterium tumefaciens (AtDPE, 283 amino acid residues, $30,650 \mathrm{Da}$ ) was reported to efficiently catalyze epimerization of not only D-tagatose to D-sorbose, but also D-fructose to D-psicose $[12,13]$. AtDPE has a sequence similarity of $39 \%$ with PcDTE. However, there are significant differences in enzymatic properties between them. For instance, PcDTE shows the highest epimerization activity toward D-tagatose, while AtDPE has higher bioconversion rate toward D-psicose than PcDTE [13]. Furthermore, the crystal structures of AtDPE and PcDTE were reported $[14,15]$, suggesting that both enzymes showed a $(\beta / \alpha)_{8}$ TIM barrel fold with a $\mathrm{Mn}^{2+}$ metal ion in the active site. Two glutamate residues and a metal ion conduct the epimerization reaction analogous to the catalytic mechanism of D-ribose5-phosphate 3-epimerase. Protein engineering was performed on PcDTE to improve its catalytic activity using its structural information [16]. Based on the structural information $[8,14,15,17,18]$, DTE and DPE shared the same catalytic mechanism of deprotonation/protonation at $\mathrm{C} 3$ by two Glu residues. One of the Glu residues removes a proton from $\mathrm{C} 3$ to generate a cis-enediolate intermediate, and then the other one protonates $\mathrm{C} 3$ on the opposite side.

A novel identified DTE from Rhodobacter sphaeroides (RsDTE) has shown the highest activity for D-fructose with a bioconversion rate to D-psicose of $23 \%$ at $40{ }^{\circ} \mathrm{C}$ and pH 9.0 [11]. However, the reason why RsDTE showed a high specificity for $\mathrm{D}$-fructose remains unclear. The structure analysis will provide more information for the catalytic reaction. In this study, the RsDTE was purified, crystallized and characterized. The substrate-binding site was analyzed based on RsDTE homology model. The research on DTE/DPE enzymes attracts enormous commercial interest and would be widely used for rare sugar production in the future.

\section{Methods}

\section{Cloning and expression}

Genomic DNA of DTE was prepared from R. sphaeroides strain as previously described [11] and was used as a template for genomic polymerase chain reaction (PCR) with the PrimeSTAR HS DNA polymerase (TaKaRa, Dalian, China) and a pair of specific primers, F: (5'-GGAATTCCATATGAAAAATCCTGTCGGCATCATCTCG-3') and R: (5'-CCGGAATTCTCAGTGGGTCACCTCCGCC-3'), for the $5^{\prime}$ - and $3^{\prime}$-untranslated regions, respectively. PCR was conducted using temperature settings of $95^{\circ} \mathrm{C}$ for 5 min followed by 30 cycles of $95{ }^{\circ} \mathrm{C}$ for $15 \mathrm{~s}, 55^{\circ} \mathrm{C}$ for
$15 \mathrm{~s}$ and $72{ }^{\circ} \mathrm{C}$ for $45 \mathrm{~s}$. The final step for extension was $72{ }^{\circ} \mathrm{C}$ for $2 \mathrm{~min}$. The RsDTE gene (GenBank Accession No. NC_007494.2) was cloned into the vector pET28a(+) (Novagen, Madison, WI, USA) between the NdeI and EcoRI sites (Additional file 1: Figure S1) with 20 residues (MGSSHHHHHHSSGLVPRGSH) at the N-terminus, including $\mathrm{His}_{6}$ tag and thrombin digestion site. E. coli BL21(DE3) cells harboring the pET28a $(+)$ plasmid with the RsDTE gene (pET28a-RsDTE) were transformed and grown in Lysogeny broth (LB) at $37{ }^{\circ} \mathrm{C}$. Isopropyl $\beta$-D-1-thiogalactopyranoside (IPTG) was added at a final concentration of $0.5 \mathrm{mM}$ when the $\mathrm{OD}_{600}$ value reached 0.6 , and the cultures were further incubated at $25{ }^{\circ} \mathrm{C}$ overnight.

\section{Purification of RsDTE enzyme}

After harvesting by centrifugation at $5000 \mathrm{~g}$ and $4{ }^{\circ} \mathrm{C}$ for $15 \mathrm{~min}$, the cells were resuspended in $100 \mathrm{~mL}$ lysis buffer (20 mM Tris- $\mathrm{HCl}$ pH 8.0, $10 \mathrm{mM}$ imidazole, $0.5 \mathrm{M} \mathrm{NaCl}$, and $1 \mathrm{mM}$ dithiothreitol), disrupted by sonication using an ultrasonicator, set at $1 \mathrm{~s}$ pulse, $1 \mathrm{~s}$ output and $50 \%$ duty cycle for $30 \mathrm{~min}$, and the cell debris was removed by centrifugation at $40,000 \mathrm{~g}$ at $4{ }^{\circ} \mathrm{C}$ for $30 \mathrm{~min}$. Cleared lysate was trapped on $3 \mathrm{~mL}$ of Ni-NTA Superflow resin (Qiagen, Hilden, Germany). After washing with $10 \mathrm{~mL}$ lysis buffer, the protein was eluted with $15 \mathrm{~mL}$ elution buffer (20 mM Tris- $\mathrm{HCl} \mathrm{pH}$ 8.0, $300 \mathrm{mM}$ imidazole, $100 \mathrm{mM}$ $\mathrm{NaCl}$, and $1 \mathrm{mM}$ dithiothreitol). The eluted solution was dialyzed against $20 \mathrm{mM}$ Tris- $\mathrm{HCl} \mathrm{pH}$ 8.0, $1 \mathrm{mM}$ dithiothreitol and was further purified by ion exchange using Source Q 4.6/100 PE (volume: $1 \mathrm{~mL}$, flow rate: $3 \mathrm{~mL} / \mathrm{min}$, GE Healthcare) and gel filtration chromatography using a Superdex 200 column 10/300 GL (volume: $24 \mathrm{~mL}$, flow rate: $0.5 \mathrm{~mL} / \mathrm{min}$, GE Healthcare) in running buffer of $20 \mathrm{mM}$ Tris- $\mathrm{HCl} \mathrm{pH}$ 8.0, $100 \mathrm{mM} \mathrm{NaCl}$, and $1 \mathrm{mM}$ dithiothreitol $[19,20]$. The concentration of total protein after each purification step was determined by the BCA assay following to the manufacturer's protocol. The amount and purity of target protein were analyzed by SDS-PAGE and densitometry of CBB-stained gels using Image Lab Software (Bio-Rad, Hercules, California, USA). The resulting solution containing RsDTE was used for activity assays.

\section{CD measurement}

Circular dichroism (CD) spectra (190-250 nm) were recorded using a MOS-450 CD spectropolarimeter (Biologic, Claix, Charente, France) with a $1 \mathrm{~mm}$ path-length cell at room temperature. The spectra were obtained as the average of four scans with a bandwidth of $0.1 \mathrm{~nm}$, a step resolution of $0.1 \mathrm{~nm}$ and a scan rate of $1 \mathrm{~nm} / \mathrm{s}$. The CD spectra of RsDTE $(0.08 \mathrm{mg} / \mathrm{mL})$ were recorded in $20 \mathrm{mM}$ Tris- $\mathrm{HCl}(\mathrm{pH} 8.0), 0.1 \mathrm{M} \mathrm{NaCl}$, and $1 \mathrm{mM}$ 
DTT. Analysis of the protein secondary structure was performed using the program SELCON3 (http://www. dichroweb.cryst.bbk.ac) [21].

\section{Confirmation of the product D-psicose using HPLC and NMR}

The product D-psicose was analyzed on a high-performance liquid chromatography (HPLC) system equipped with a Prevail Carbohydrate ES column-W (5 $\mu \mathrm{m}$, $4.6 \times 250 \mathrm{~mm}$, Agela Technologies, China), an Agilent (USA) multichannel interface, and a XWK-III pump. Acetonitrile (85\%) was used as the eluent at a flow rate of $1 \mathrm{~mL} / \mathrm{min}$. The column temperature was kept at $40{ }^{\circ} \mathrm{C}$. The product was detected using an evaporative lightscattering detector (Agilent 1260 Infinity, USA).

The ${ }^{1} \mathrm{H}$ and ${ }^{13} \mathrm{CNMR}$ spectra were recorded in $\mathrm{D}_{2} \mathrm{O}$ on a Bruker AV-500 spectrometer at working frequencies 400 and $100 \mathrm{MHz}$, respectively. Chemical shifts are expressed in ppm $(\delta)$ values and coupling constants $(\delta)$ in $\mathrm{Hz}$.

\section{Activity assay}

The activity was determined by measuring D-psicose formation using $\mathrm{D}$-fructose as a substrate [22, 23]. The reactions were performed carried out with $5 \mu \mathrm{M}$ RsDTE, $10 \mathrm{~g} / \mathrm{L} \mathrm{D}$-fructose and $10 \mu \mathrm{M} \mathrm{Mn}{ }^{2+}$ in $20 \mathrm{mM}$ Tris- $\mathrm{HCl}$ buffer ( $\mathrm{pH} 8.5)$ at $35{ }^{\circ} \mathrm{C}$ for $10 \mathrm{~min}$. After the reaction, D-psicose was measured using HPLC.

The optimal $\mathrm{pH}$ of the purified enzyme was determined in the following buffers: $20 \mathrm{mM}$ MES buffer (pH 5.5-6.5), $20 \mathrm{mM}$ PBS buffer (pH 7.0-8.0), $20 \mathrm{mM}$ Tris- $\mathrm{HCl}$ buffer (pH 8.5-9.0) and $20 \mathrm{mM}$ CAPS buffer (pH 9.5-11.0) at $35{ }^{\circ} \mathrm{C}$ for $10 \mathrm{~min}$. The optimal temperature was determined by incubating RsDTE at different temperatures ranging from 20 to $70{ }^{\circ} \mathrm{C}$. To determine the effect of metal ions on the activity of RsDTE, $0.1 \mathrm{mM}$ final concentrations of $\mathrm{Ca}^{2+}, \mathrm{Mg}^{2+}, \mathrm{Mn}^{2+}, \mathrm{Ni}^{2+}, \mathrm{Co}^{2+}, \mathrm{Zn}^{2+}, \mathrm{Cu}^{2+}$, $\mathrm{Fe}^{2+} \mathrm{Fe}^{3+}$ and EDTA were added to the reaction system. The activity was then measured under standard reaction conditions. All assays were repeated three times, and the data are shown as mean \pm SD.

\section{Crystallization of RsDTE}

Crystallization of RsDTE was performed with the sparsematrix screening kits Crystal Screen HT (Hampton Research), Index HT (Hampton Research), Wizard I and II (Emerald BioSystems) and JCSG+ (Qiagen) in 96-well plates using the sitting-drop vapour-diffusion method. For refinement of the crystallization conditions, $0.5 \mu \mathrm{L}$ of protein was mixed with an equal volume of reservoir solution and equilibrated against $0.5 \mu \mathrm{L}$ of reservoir solution at $20^{\circ} \mathrm{C}$ in 96 -well plates. The $\mathrm{X}$-ray diffraction data for RsDTE crystals were collected using an in-house
X-ray diffractometer (Rigaku FR-E rotating-anode X-ray generator with R-AXIS VII imaging-plate detector).

\section{Structure modeling of RsDTE}

The three-dimensional (3D) homology model of RsDTE was generated using Modeller 9.9 [24]. The crystal structure of PcDTE (PDB ID: 2QUL, $1.79 \AA$ ), which has $31 \%$ sequence identity to the target protein RsDTE, was chosen as the template. The align $2 \mathrm{~d}$ command was used to automatically generate a sequence alignment between the template and RsDTE. Subsequently, homology modeling was performed by the automodel command. Thereafter, each model was first optimized by the variable target function method with conjugate gradients. Simulated annealing MD simulations were used to refine the structure. Finally, the best model was chosen from the values of the Modeller objective function and the DOPE assessment scores. The PyMol molecular Graphics System (http://www.pymol.org) [25] was used to visualize and analyze the generated model structure.

\section{Site-directed mutagenesis}

The RsDTE mutants were generated using a one-step PCR method with plasmid RsDTE_pET28a wild-type as the template. The primers used for mutagenesis are summarized in Additional file 1: Table S1. After amplification, the PCR reaction mixtures were treated with $D p n \mathrm{I}$ to completely digest the template and then transformed into E. coli JM109 cells. All the mutations were confirmed by DNA sequencing. Genes of RsDTE mutants were expressed and proteins were purified using the method described above for wild-type enzyme.

\section{Results and discussion}

Gene cloning, overexpression of RsDTE and purification of enzyme

The DTE gene was amplified by PCR using the genomic DNA of $R$. sphaeroides as a template. The results showed that this gene contained $885 \mathrm{bp}$ of a complete open reading frame encoding a protein (295 amino acids, $31.75 \mathrm{kDa}$ ). This gene was deposited in GenBank with the Accession Number NC_007494.2. The recombinant plasmid (pET28a-RsDTE) was confirmed by double-enzyme digestion with NdeI and EcoRI (Additional file 1: Figure S1) and gene sequencing. The results show that the RsDTE gene was subcloned into pET28a plasmid, and the expression vector was constructed successfully.

When recombinant RsDTE was overexpressed in $E$. coli BL21(DE3), soluble and insoluble fractions were separated by centrifugation after cell lysis and analyzed using SDS-PAGE (Additional file 1: Figure S2). The eluted fractions were then further purified by anion-exchange chromatography using an AKTA system (Fig. 1a). The 


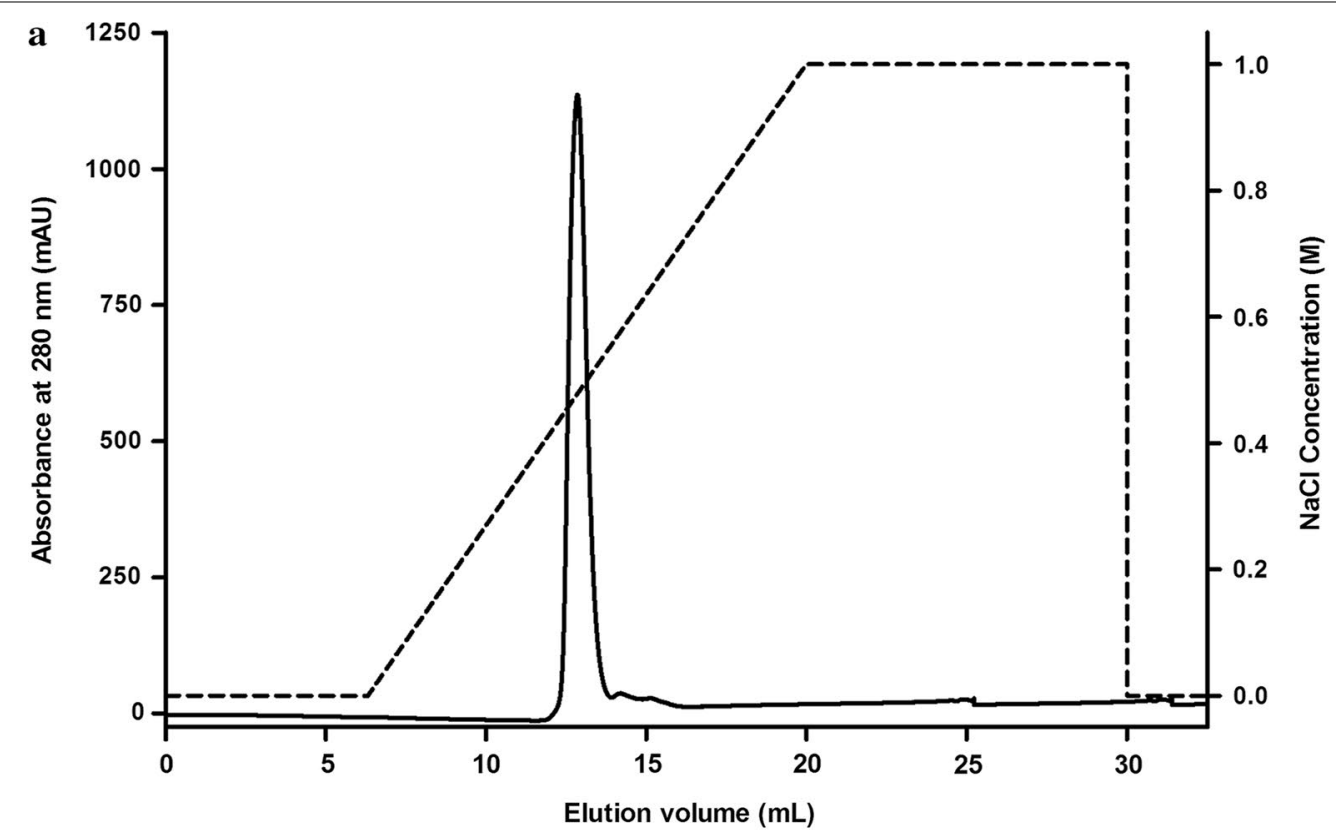

b
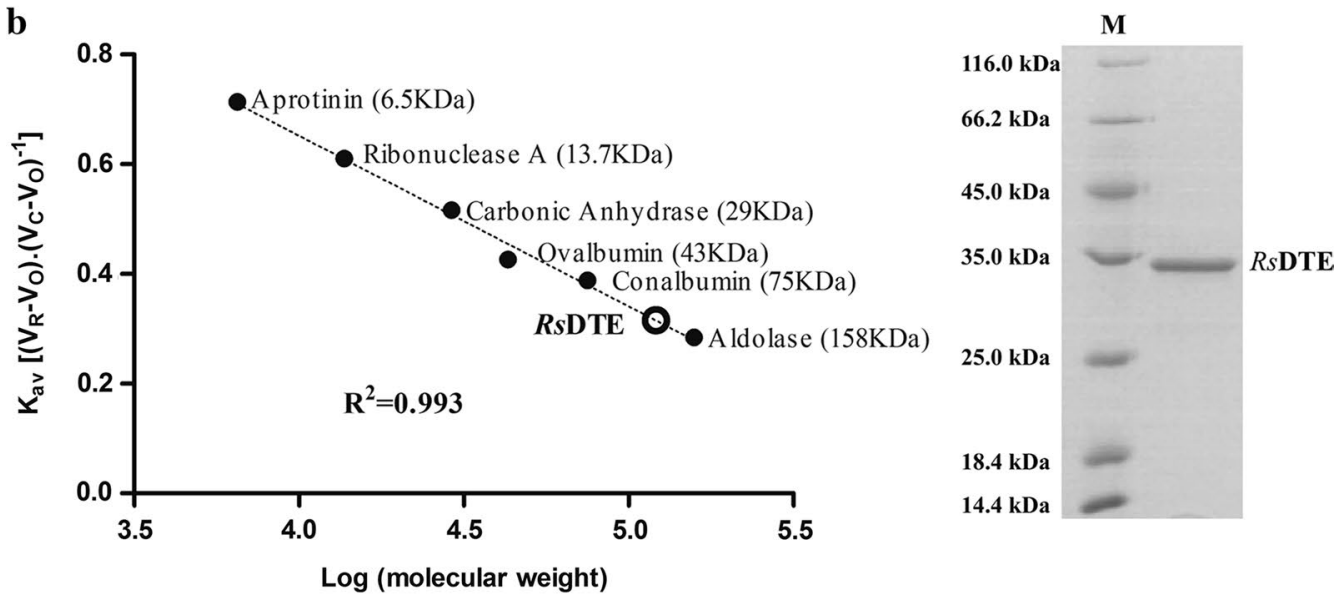

c

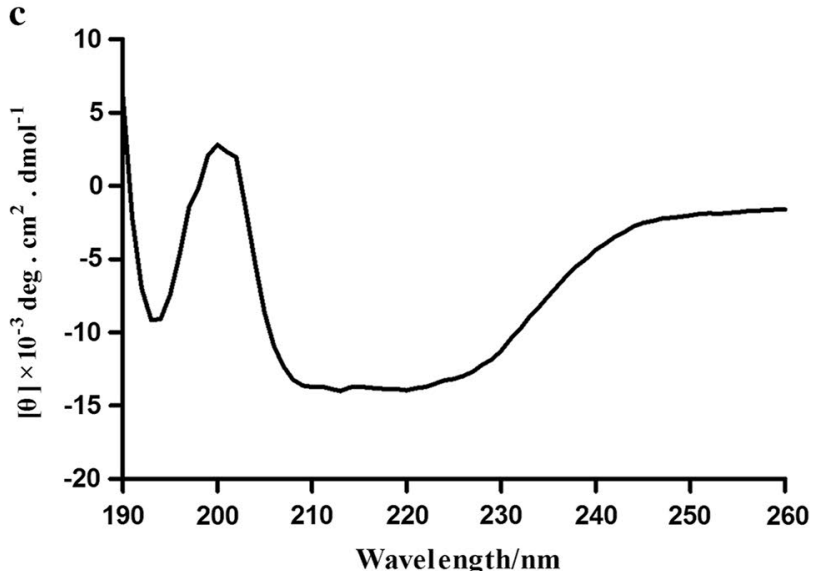

Fig. 1 Purification of RsDTE by anion-exchange (a) and size-exclusion chromatography (b). CD spectra of RsDTE (c). $1 \mathrm{mg} / \mathrm{mL}$ of six standard protein markers (mass weight: 6.5, 13.7, 29, 43, 75 and $158 \mathrm{kDa}$ ) was used for canonical plotting of gel filtration analysis. 50 and $5 \mu \mathrm{g}$ of purified RsDTE were used for gel filtration and SDA-PAGE analysis, respectively. $0.08 \mathrm{mg} / \mathrm{mL}$ of purified RsDTE was used for CD spectroscopy 
results showed that a single major peak was detected at $280 \mathrm{~nm}$ in the purified protein fraction. SDS-PAGE indicated that highly purified DTE protein was obtained. The molecular mass of RsDTE in solution was estimated by size-exclusion chromatography, and a single peak corresponding to a tetramer was observed (Fig. 1b; Additional file 1: Figure S3).

The structural features of RsDTE were evaluated using CD spectroscopy (Fig. 1c and Table 1). The CD spectrum of RsDTE showed a positive absorption peak centered around $200 \mathrm{~nm}$. The $\alpha$-helix and $\beta$-strand regions constituted 34.5 and $11 \%$, of the total secondary structure, respectively.

\section{Characterization of RsDTE and product confirmation}

The product D-psicose was confirmed by HPLC with a retention time of $12.37 \mathrm{~min}$ (Fig. 2). NMR spectroscopy was used to confirm identity and structure of D-psicose (Additional file 1: Figure S4). Spectral data for hydrocarbons were analyzed as follows: ${ }^{1} \mathrm{H}$ NMR $\left(400 \mathrm{MHz}, \mathrm{D}_{2} \mathrm{O}\right)$ : $\delta=3.45(\mathrm{~d}, J=11.86 \mathrm{~Hz}), 3.57-3.86(\mathrm{~m}), 3.96-4.10(\mathrm{~m})$, $4.21(\mathrm{~m}), 4.35 \mathrm{ppm}(\mathrm{dd}, J=7.64,4.68 \mathrm{~Hz}) ;{ }^{13} \mathrm{C} \mathrm{NMR}$ $\left(100 \mathrm{MHz}, \mathrm{D}_{2} \mathrm{O}\right): \delta=105.59,103.24,98.40,97.66,82.69$, $82.67,74.63,71.70,70.98,70.33,70.30,70.21,68.99$, $65.83,65.48,65.05,64.15,63.96,63.24,63.04,62.78$, $62.36,61.31,57.95$.

Table 1 Secondary-structure contents of RsDTE determined by $C D$ spectroscopy in the wavelength region from 190 to $260 \mathrm{~nm}$

\begin{tabular}{lllll}
\hline Protein & \multicolumn{4}{l}{ Secondary structure (\%) } \\
\cline { 2 - 5 } & $\mathbf{a}$-Helix & $\boldsymbol{\beta}$-Strand & Turn & Unordered \\
\hline DTE & 34.5 & 11.0 & 23.1 & 31.3 \\
\hline
\end{tabular}

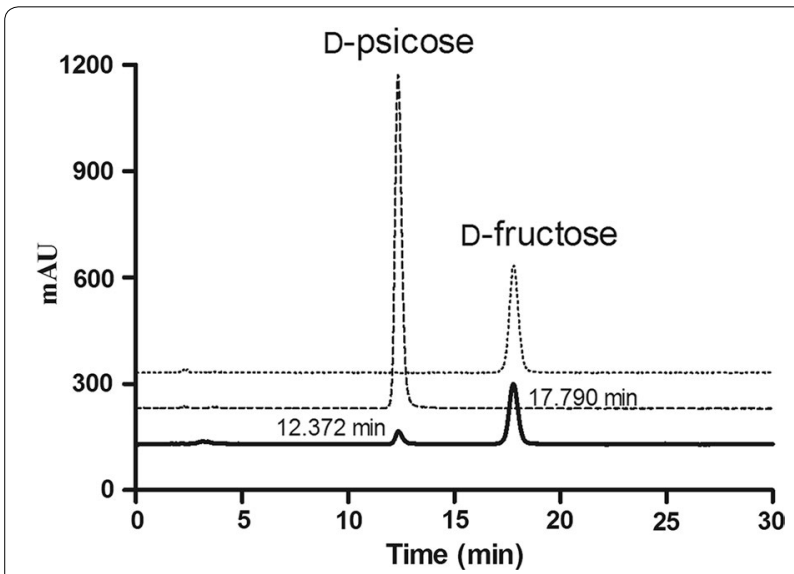

Fig. 2 Confirmation of the enzymatic conversion product D-psicose using HPLC
The catalytic activity of RsDTE is highly dependent on the buffer composition, $\mathrm{pH}$ and temperature. The purified WT RsDTE was active at pH 5.5-11.0 and the maximal activity was observed in Tris- $\mathrm{HCl}$ buffer $\mathrm{pH}$ 8.5 (Fig. 3a). The optimal temperature for RsDTE activity was $35^{\circ} \mathrm{C}$. The activity began to decrease when the temperature was $>40^{\circ} \mathrm{C}$ (Fig. 3b). The activity of RsDTE was affected by several metal ions (Fig. 3c). Adding $0.1 \mathrm{mM}$
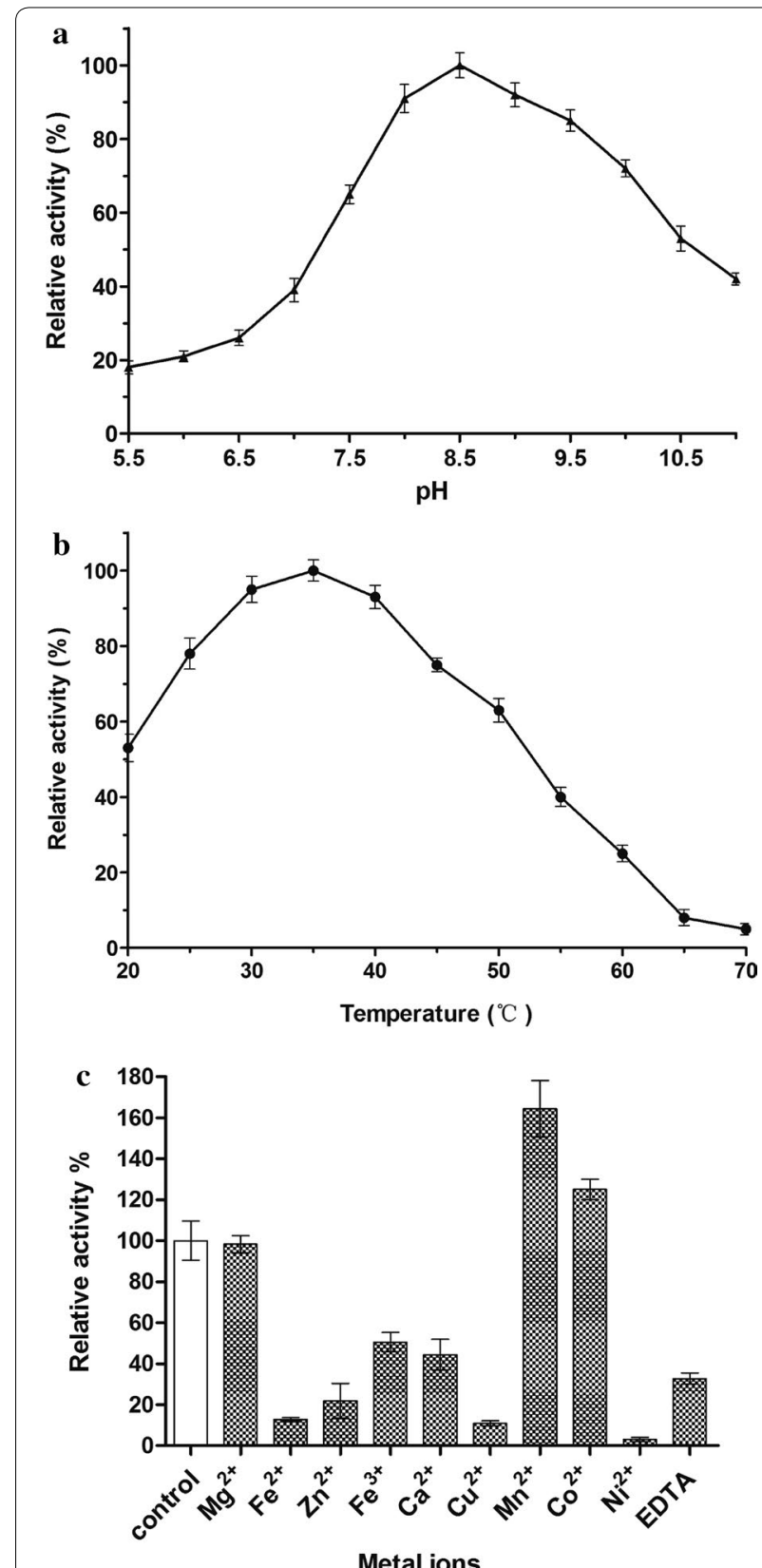

Fig. 3 Effect of $\mathrm{pH}(\mathbf{a})$, temperature (b) and metal ions (c) on activity of RsDTE. The activity of purified RsDTE using AKTA system was determined in standard assay conditions as control and all of the enzyme samples were not treated with EDTA 
Table 2 Kinetic parameters of RsDTE wild-type on four substrates

\begin{tabular}{|c|c|c|c|c|c|}
\hline Enzymes & Substrates & $K_{\mathrm{m}}(\mathrm{mM})$ & $k_{\text {cat }}\left(\mathrm{s}^{-1}\right)$ & $k_{\mathrm{cat}} / K_{\mathrm{m}}\left(\mathrm{s}^{-1} \mathrm{mM}^{-1}\right)$ & Relative activity (\%) \\
\hline \multirow[t]{4}{*}{ WT } & D-Fructose & $78 \pm 2.3$ & $42.60 \pm 0.89$ & $0.55 \pm 0.008$ & 100 \\
\hline & D-Psicose & $215 \pm 4.8$ & $20.47 \pm 0.63$ & $0.10 \pm 0.005$ & $23.2 \pm 1.8$ \\
\hline & D-Tagatose & $138 \pm 0.8$ & $48.31 \pm 0.52$ & $0.35 \pm 0.006$ & $69.1 \pm 2.3$ \\
\hline & D-Sorbose & $359 \pm 3.5$ & $8.30 \pm 0.34$ & $0.02 \pm 0.001$ & $4.5 \pm 0.4$ \\
\hline \multirow[t]{4}{*}{ R118W } & D-Fructose & $162 \pm 4.2$ & $41.05 \pm 0.43$ & $0.25 \pm 0.008$ & $58.46 \pm 3.9$ \\
\hline & D-Psicose & $193 \pm 6.2$ & $26.04 \pm 0.58$ & $0.14 \pm 0.008$ & $22.78 \pm 2.7$ \\
\hline & D-Tagatose & $98 \pm 3.5$ & $51.25 \pm 0.54$ & $0.52 \pm 0.013$ & 100 \\
\hline & D-Sorbose & $148 \pm 2.8$ & $15.36 \pm 0.44$ & $0.10 \pm 0.001$ & $16.28 \pm 1.6$ \\
\hline
\end{tabular}

All assays were repeated three times, and the data are shown as mean $\pm \mathrm{SD}$

$\mathrm{MnCl}_{2}$ and $\mathrm{CoCl}_{2}$ to the reaction mixture increased the activity by 60 and $25 \%$, respectively, which suggests that $\mathrm{Mn}^{2+}$ activates the catalytic reaction of RsDTE. RsDTE lost almost all activity when $\mathrm{CuCl}_{2}$ was added to reaction system. EDTA may not completely chelate all the metals because it still retained $33 \%$ of the residual activity. The results support the reports point that RsDTE is a metalloenzyme $[13,22]$.

The kinetic parameters of RsDTE on different substrates are summarized in Table 2 and Fig. 4. RsDTE was characterized by $K_{\mathrm{m}}$ values of between 78 and $359 \mathrm{mM}$, and catalytic efficiencies of between 0.02 and $0.55 \mathrm{~s}^{-1} \mathrm{mM}^{-1}$. RsDTE showed a high activity toward $\mathrm{D}$-fructose and a low activity toward D-sorbose.

\section{Crystallization of RsDTE}

We obtained the apo-RsDTE crystals (Additional file 1: Figure S5) in crystallization conditions as shown in Additional file 1: Table S2 after 3 days. The crystallization conditions were further refined in different $\mathrm{pHs}$

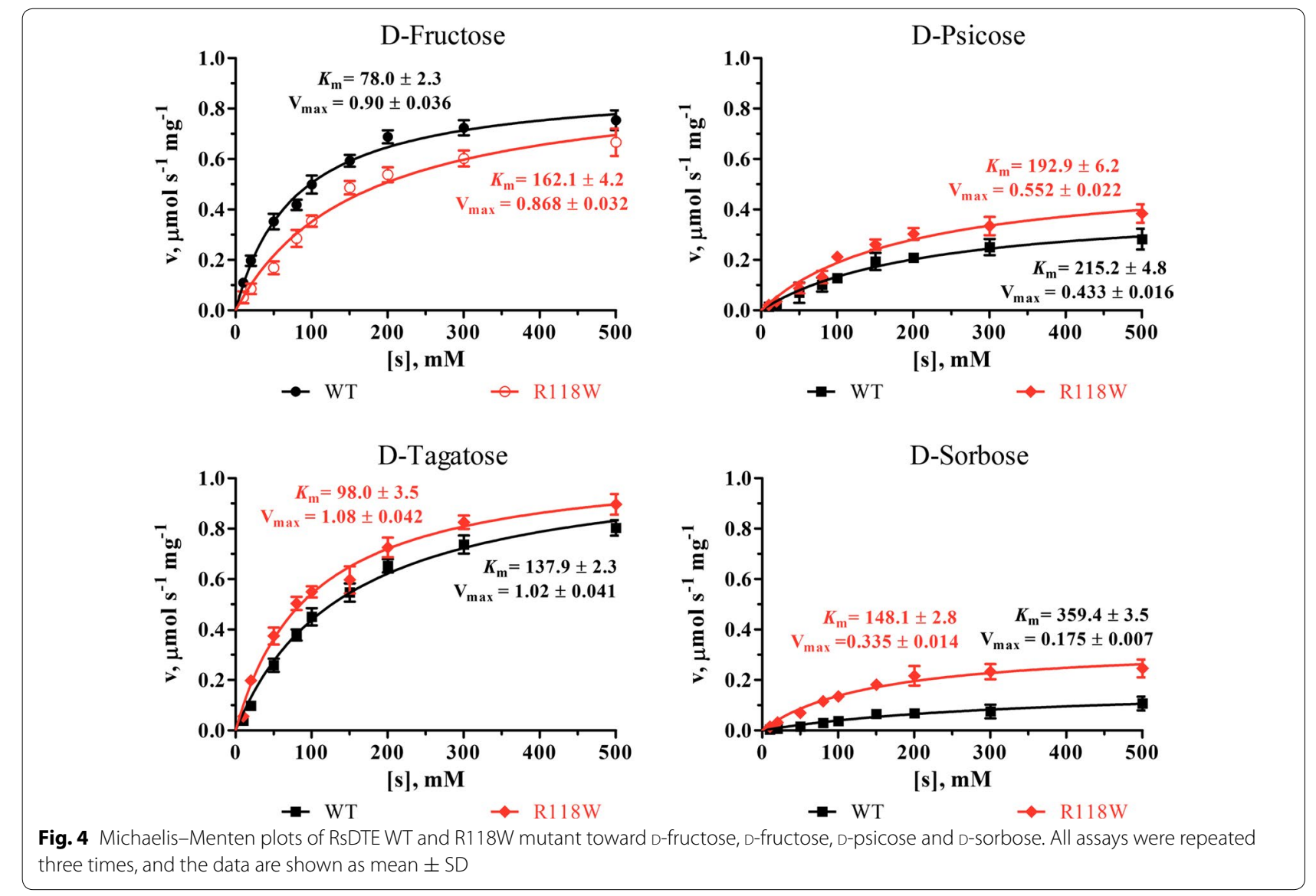


and precipitants as followings: (A) 10\% PEG 8000, $0.1 \mathrm{M}$ HEPES pH 7.5, 8\% ethylene glycol; (B) 12\% PEG 20,000, 0.1 M MES pH 6.5; and (C) 12\% PEG 8000, 0.1 M HEPES $\mathrm{pH} 7.5,8 \%$ ethylene glycol at $20{ }^{\circ} \mathrm{C}$ in 96 -well plates (Additional file 1: Figure S6). X-ray diffraction data were collected to about 5-6 Å resolution. Additional file 1: Figure $\mathrm{S} 7$ shows an X-ray diffraction image of the RsDTE crystal. The crystal needs to be further refined to obtain higher resolution for structure determination.

\section{Phylogenetic tree analysis of RsDTE}

A search for enzymes with different amino acid sequence identities above $40 \%$ was performed using BLAST. These sequential and homologous proteins were compared with RsDTE (Additional file 1: Figure S8). RsDTE was very similar in sequence to its homologs in Pannonibacter phragmitetus (WP_050473007.1), Paracoccus alcaliphilus (SEN75178.1) and Poseidonocella pacifica (SFB17294.1), which shares the sequence identities of 84,82 and $77 \%$ with these family members, respectively. The crystal structures of DTE from P. cichorii, A. fabrum str. C58, C. cellulolyticum $\mathrm{H} 10$ and T. maritime were determined, however, they only shared $28,30,36$ and $20 \%$ sequence identity with RsDTE, respectively.

\section{Homology modeling of RsDTE}

We generated a structural homology model of RsDTE using the crystal structure of D-tagatose 3-epimerase from P. Cichorii (PDB ID: 2QUL, $1.79 \AA$ ), which has $31 \%$ sequence identity to the target protein RsDTE [15]. The structure of RsDTE (Fig. 5a) contained $8 \beta$-strands, $10 \alpha$-helices and two $3_{10}$ helices. RsDTE possessed the characteristic TIM-barrel $(\beta / \alpha)_{8}$ fold consisting of eight repetitive units of $\beta$-strand $/ \alpha$-helix as the main structural motif, with a cluster of $\beta$-strands surrounded by $\alpha$-helices in the center of the molecule. The other two $\alpha$-helices $(\alpha 6$ and $\alpha 9)$ and two $3_{10}$ helices were packed together along with the TIM barrel.

\section{Characteristics of the active site}

The modeling structure of RsDTE shows that there were four residues, Glu156, Asp189, Gln215 and Glu250, around the metal-binding site, which form a hydrogen bond network for the hydride transfer reaction (Fig. 5b). This result strongly suggests that these residues constitute the catalytic tetrad of RsDTE, which is partly conserved in the DTE/DPE superfamily (Fig. 5c). Three residues of Glu156, Asp189 and Glu250 were completely conserved. However, Gln215 was not conserved, in which histidine is positioned, instead of glutamate, in P. cichorii, A. tumefaciens, C. cellulolyticum and T. maritime. The substrate $\mathrm{D}$-fructose coordinated $\mathrm{Mn}(\mathrm{II})$ in a bidentate manner using its $\mathrm{O} 2$ and $\mathrm{O} 3$ groups, which form a

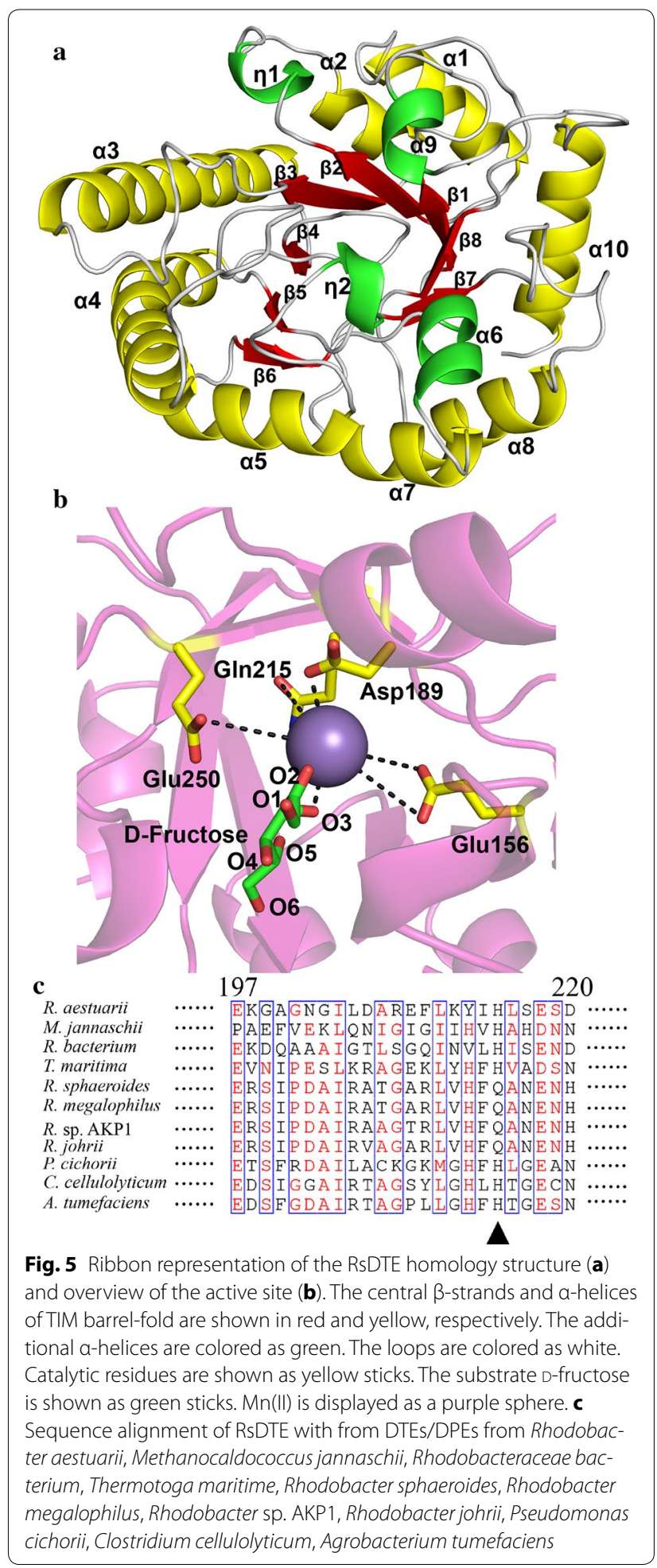

distorted octahedral coordination geometry complex (Fig. 5b). This modeling structure supports the previously proposed mechanism of deprotonation/protonation at 


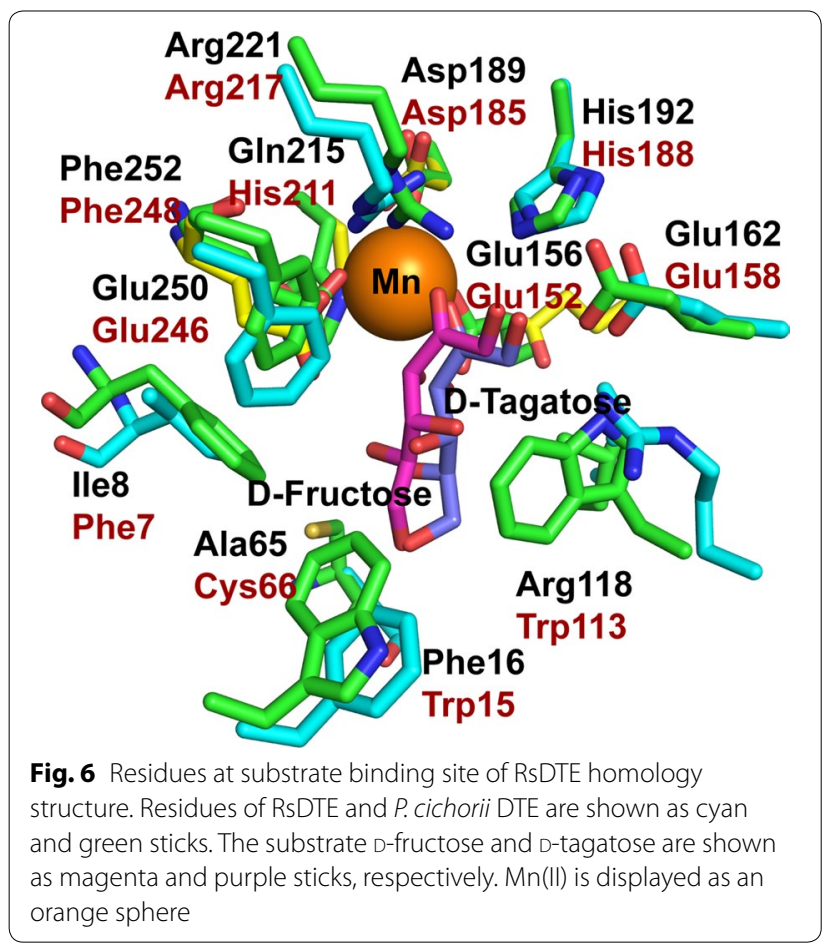

C3 of substrate by two Glu residues (Glu156 and Glu250) $[14,15,18]$.

\section{Proposal interactions between enzyme and substrates}

The $\mathrm{O} 1$ of substrate D-fructose formed hydrogen bonds with His192 and Glu162 to help the correct metal coordination of the substrate (Fig. 6). The $\mathrm{O} 2$ formed hydrogen bonds with His192 and Arg221. Glu156 formed hydrogen bonds with O3, and Glu250 directed its OE2 atom to a hydrogen atom attached to $\mathrm{C} 3$. Because $\mathrm{D}$-fructose has the same configurations of $\mathrm{C} 1, \mathrm{C} 2$ and $\mathrm{C} 3$ as D-tagatose, the interactions between $\mathrm{D}$-fructose at the 1-, 2- and 3 -positions and the enzyme were very similar to those in other DTE/DPE family enzymes [14, 15, 18]. However, the residues, which interact with $\mathrm{D}$-fructose/D-tagatose at 4-, 5- and 6-positions were not conserved with these family enzymes (Fig. 6; Additional file 1: Figure S9). Ile8 (Trp in P. cichorii, A. tumefaciens and Tyr in C. cellulolyticum), Ala65 (Cys in P. cichorii and Gly in A. tumefaciens and C. cellulolyticum), Phe16 (Trp in P. cichorii, A. tumefaciens and C. cellulolyticum) and Phe252 (Phe in P. cichorii, A. tumefaciens and C. cellulolyticum) may form a hydrophobic pocket to interact with $\mathrm{O} 4, \mathrm{O} 5$ and O6 of D-fructose/D-tagatose. Arg118 (Trp in P. cichorii, A. tumefaciens and C. cellulolyticum) formed a unique hydrogen bond with $\mathrm{O} 4$, which prefers to recognize $\mathrm{D}$-fructose than D-tagatose. To investigate the role of Arg118 in substrate recognition of RsDTE, we mutated
Arg118 to tryptophan. RsDTE wild-type showed lower Michaelis-Menten constant $\left(K_{\mathrm{m}}\right)$, lower turnover number $\left(k_{\text {cat }}\right)$, but higher catalytic efficiency $\left(k_{\text {cat }} / K_{\mathrm{m}}\right)$ values for D-fructose than for D-psicose. The $k_{\text {cat }} / K_{\mathrm{m}}$ for D-fructose was 5.5-fold higher than for D-psicose, indicating that RsDTE highly catalyzed D-fructose, although it was a D-tagatose 3-epimerase. However, RsDTE_R118W mutant led to the decreased catalytic activity compared with the wild-type enzyme toward D-fructose (Table 2). The $k_{\text {cat }} / K_{\mathrm{m}}$ for D-tagatose was about twofold higher than for D-psicose. Notably, R118 W showed 1.5-fold higher catalytic efficiency toward D-tagatose than wild-type, implying that Arg118 may regulate the substrate specificity. The unique hydrogen bond with Arg118 and O4 of D-fructose may be broken when muted to Trp. The strengthened hydrophobic interaction may attribute to the recognition of $\mathrm{D}$-tagatose, $\mathrm{D}$-psicose and $\mathrm{D}$-sorbose (Fig. 6). The structure information supports the biochemical data that Arg118 regulates the substrate specificity.

\section{Conclusions}

The purified D-tagatose 3-epimerase from Rhodobacter sphaeroides catalyzes the epimerization of D-fructose to D-psicose at the C3 position. RsDTE shows optimal conditions in Tris- $\mathrm{HCl} \mathrm{pH} 8.5$ at $35^{\circ} \mathrm{C}$. RsDTE was crystallized under refined crystallization conditions. Arg118 around the substrate-binding site was investigated, and R118 W improves the substrate recognition and activity. Consistent with biochemical data, R118 forms a hydrogen bond with $\mathrm{O} 4$ of $\mathrm{D}$-fructose. The research of RsDTE in its active form provides a valuable tool for solving this enzyme's crystal structure in the future.

\section{Additional file}

Additional file 1. Additional tables and figures.

\section{Authors' contributions}

FL and H-MQ designed the research; ZQ, ZZ, SL and J-WW performed the experiments; ZQ, QG and PX analyzed data; H-MQ, FL and ZQ wrote the paper. All authors read and approved the final manuscript.

\section{Author details}

${ }^{1}$ Key Laboratory of Industrial Fermentation Microbiology, Ministry of Education, Tianjin, People's Republic of China. ${ }^{2}$ Tianjin Key Laboratory of Industrial Microbiology, Tianjin, People's Republic of China. ${ }^{3}$ College of Biotechnology, Tianjin University of Science and Technology, Tianjin, People's Republic of China. ${ }^{4}$ National Engineering Laboratory for Industrial Enzymes, Tianjin 300457, People's Republic of China.

\section{Acknowledgements}

We thank Stewart Dods, Ph.D., from Liwen Bianji, Edanz Editing China (http://www.liwenbianji.cn/ac), for editing the English text of a draft of this manuscript.

\section{Competing interests}

The authors declare that they have no competing interests. 


\section{Availability of data and materials}

The data collected upon which this article is based upon are all included in this manuscript and the additional files associated with it.

\section{Consent for publication}

Our manuscript does not contain any individual data in any form.

\section{Ethics approval and consent to participate}

No animals or human subjects were used in the above research.

\section{Funding}

This work was supported by National Key Research and Development Project (2016YFD0400803), National Natural Science Foundation of China (31771911), Natural Science Foundation of Tianjin (16JCQNJC09200) and the Overseas High-level Talents Program of Tianjin University of Science and Technology to H.-M. Qin, China, National High Technology Research and Development Program (SS2015AA020601), Science Foundation of Tianjin University of Science and Technology (2015LG22).

\section{Publisher's Note}

Springer Nature remains neutral with regard to jurisdictional claims in published maps and institutional affiliations.

Received: 12 August 2017 Accepted: 1 November 2017

Published online: 09 November 2017

\section{References}

1. Matsuo T, Izumori K. Effects of dietary D-psicose on diurnal variation in plasma glucose and insulin concentrations of rats. Biosci Biotechnol Biochem. 2006;70:2081-5.

2. Matsuo T, Suzuki H, Hashiguchi M, Izumori K. D-Psicose is a rare sugar that provides no energy to growing rats. J Nutr Sci Vitaminol. 2002;48:77-80.

3. Lu Y, Levin GV, Donner TW. Tagatose, a new antidiabetic and obesity control drug. Diabetes Obes Metab. 2008;10:109-34.

4. Matsuo T, Baba Y, Hashiguchi M, Takeshita K, Izumori K, Suzuki H. Dietary D-psicose, a C-3 epimer of D-fructose, suppresses the activity of hepatic lipogenic enzymes in rats. Asia Pac J Clin Nutr. 2001;10:233-7.

5. Emmadi M, Kulkarni SS. Recent advances in synthesis of bacterial rare sugar building blocks and their applications. Nat Prod Rep. 2014:31:870-9.

6. Zhang WL, Zhang T, Jiang B, Mu WM. Enzymatic approaches to rare sugar production. Biotechnol Adv. 2017:35:267-74.

7. Granstrom TB, Takata G, Tokuda M, Izumori K. Izumoring: a novel and complete strategy for bioproduction of rare sugars. J Biosci Bioeng. 2004;97:89-94.

8. van Overtveldt S, Verhaeghe T, Joosten HJ, van den Bergh T, Beerens K, Desmet T. A structural classification of carbohydrate epimerases: from mechanistic insights to practical applications. Biotechnol Adv. 2015:33:1814-28.

9. Ishida Y, Kamiya T, Izumori K. Production of D-tagatose 3-epimerase of Pseudomonas cichorii ST-24 using recombinant Escherichia coli. J Ferment Bioeng. 1997;84:348-50.

10. Itoh H, Sato T, Izumori K. Preparation of D-psicose from D-fructose by immobilized D-tagatose 3-epimerase. J Ferment Bioeng. 1995;80:101-3.
11. Zhang LT, Mu WM, Jiang B, Zhang T. Characterization of D-tagatose3-epimerase from Rhodobacter sphaeroides that converts D-fructose into D-psicose. Biotechnol Lett. 2009;31:857-62.

12. Itoh H, Okaya H, Khan AR, Tajima S, Hayakawa S, Izumori K. Purification and characterization of D-tagatose 3-epimerase from Pseudomonas sp. ST-24. Biosci Biotechnol Biochem. 1994;58:2168-71.

13. Kim HJ, Hyun EK, Kim YS, Lee YJ, Oh DK. Characterization of D-psicose 3-epimerase from Agrobacterium tumefaciens converting D-fructose into D-psicose. Appl Environ Microbiol. 2006;72:981-5.

14. Kim K, Kim HJ, Oh DK, Cha SS, Rhee S. Crystal structure of D-psicose 3-epimerase from Agrobacterium tumefaciens and its complex with true substrate D-fructose: a pivotal role of metal in catalysis, an active site for the non-phosphorylated substrate, and its conformational changes. J Mol Biol. 2006;361:920-31.

15. Yoshida H, Yamada M, Nishitani T, Takada G, Izumori K, Karnitori S. Crystal structures of D-tagatose 3-epimerase from Pseudomonas cichorii and its complexes with D-tagatose and D-fructose. J Mol Biol. 2007;374:443-53.

16. Bosshart A, Hee CS, Bechtold M, Schirmer T, Panke S. Directed divergent evolution of a thermostable D-tagatose epimerase towards improved activity for two hexose substrates. ChemBioChem. 2015:16:592-601.

17. Sakuraba H, Yoneda K, Satomura T, Kawakami R, Ohshima T. Structure of a D-tagatose 3-epimerase-related protein from the hyperthermophilic bacterium Thermotoga maritima. Acta Crystallogr Sect F Struct Biol Cryst Commun. 2009;65:199-203.

18. Chan HC, Zhu Y, Hu Y, Ko TP, Huang CH, Ren F, Chen CC, Ma Y, Guo RT, Sun Y. Crystal structures of D-psicose 3-epimerase from Clostridium cellulolyticum $\mathrm{H} 10$ and its complex with ketohexose sugars. Protein Cell. 2012;3:123-31.

19. Oin HM, Miyakawa T, Jia MZ, Nakamura A, Ohtsuka J, Xue YL, Kawashima T, Kasahara T, Hibi M, Ogawa J, Tanokura M. Crystal structure of a novel $\mathrm{N}$-substituted L-amino acid dioxygenase from Burkholderia ambifaria AMMD. PLoS ONE. 2013;8:e63996.

20. Oin HM, Yamamura A, Miyakawa T, Kataoka M, Nagai T, Kitamura N, Urano N, Maruoka S, Ohtsuka J, Nagata K, Shimizu S, Tanokura M. Structure of conjugated polyketone reductase from Candida parapsilosis IFO 0708 reveals conformational changes for substrate recognition upon NADPH binding. Appl Microbiol Biotechnol. 2014;98:243-9.

21. Whitmore L, Wallace BA. Protein secondary structure analyses from circular dichroism spectroscopy: methods and reference databases. Biopolymers. 2008;89:392-400.

22. Mu WM, Chu FF, Xing QC, Yu SH, Zhou L, Jiang B. Cloning, expression, and characterization of a D-psicose 3-epimerase from Clostridium cellulolyticum H10. J Agric Food Chem. 2011;59:7785-92.

23. Ishida Y, Kamiya $\mathrm{T}$, Itoh $\mathrm{H}$, Kimura Y, Izumori K Cloning and characterization of the $\mathrm{D}$-tagatose 3-epimerase gene from Pseudomonas cichorii ST-24. J Ferment Bioeng. 1997;83:529-34.

24. Sali A, Blundell TL. Comparative protein modelling by satisfaction of spatial restraints. J Mol Biol. 1993;234:779-815

25. Humphrey W, Dalke A, Schulten K. VMD: visual molecular dynamics. J Mol Graph. 1996;14:33-8.

\section{Submit your next manuscript to BioMed Central and we will help you at every step:}

- We accept pre-submission inquiries

- Our selector tool helps you to find the most relevant journal

- We provide round the clock customer support

- Convenient online submission

- Thorough peer review

- Inclusion in PubMed and all major indexing services

- Maximum visibility for your research

Submit your manuscript at www.biomedcentral com/submit
Ciomed Central 